\title{
REVISION OF THE ONOCOSMOECUS UNICOLOR GROUP (TRICHOPTERA: LIMNEPHILIDAE, DICOSMOECINAE)
}

\author{
By GLENN B. Wiggins ${ }^{1}$ AND John S. RichaRdSON ${ }^{2}$
}

\section{INTRODUCTION}

The genus Onocosmoecus, by current definition, comprises the unicolor group and the frontalis group (Schmid 1980, occidentalis group = unicolor group; Wiggins 1977). From a separate study of generic relationships within the Dicosmoecinae (G. B. Wiggins \& O. S. Flint, in prep.), it is clear that Onocosmoecus in this broad sense is not monophyletic. The frontalis group will be considered in a subsequent paper, but in the interim the two western North American species of which it is composed, $O$. frontalis (Banks) and $O$. schmidi (Wiggins), remain nominally under Onocosmoecus. Thus, in final analysis, this study of the unicolor group will constitute a revision of the genus Onocosmoecus s.s., and the generic name is used here in that restricted sense.

Among the genera of the limnephilid subfamily Dicosmoecinae, Onocosmoecus s.s. is one of the most widespread, represented across the whole of northern North America from Newfoundland to Alaska, south in the western mountains to California, and across the Bering Strait to Kamchatka. They are rather large caddisflies, not often found in abundance but by no means rare. Larvae occur in cool lotic habitats, and also in the littoral zone of cool lakes, where they are detritivorous. Seven species have been assigned to the genus in the past but reservations concerning their validity have been expressed by several authors (e.g., Schmid 1955, 1980; Flint 1960; Wiggins 1977). Because no analysis of types or of long series of specimens has been undertaken, identity of the putative species has always been doubtful. The purpose of the present study was to undertake that analysis.

\footnotetext{
'Department of Entomology, Royal Ontario Museum, 100 Queen's Park, Toronto, Ontario, Canada M5S 2C6.

${ }^{2}$ Department of Zoology, University of British Columbia, Vancouver, B.C. Canada. Manuscript received by the editor June 17, 1986.
} 


\section{Materials ANd Methods}

Extensive collections in the Department of Entomolgy, Royal Ontario Museum (ROM) provided the main basis for this study and were supplemented by material borrowed from other collections; deposition of all other specimens examined is given below. On the distribution map for $O$. unicolor (Fig. 14), not all records in the central part of the range are plotted. Since complete listing of all records for $O$. unicolor is too voluminous for inclusion here, an abbreviated citation is used; localities are listed under state or province and any other identifier, followed by the place of deposition of the material, and the range for adult flight records is given for each state or province. A complete listing of all records compiled is deposited in the Library of the Royal Ontario Museum. Records for larvae are included; instars are designated as LV (Larval instar V), LIV, LIII, P (Pupa), PP (Prepupa). Life history data for $O$. unicolor are grouped into weekly intervals for plotting (Fig. 10), with each dot representing a collection comprising one or more individuals at a given stage. Larvae were identified to the third instar, although some characters are not as well developed as in the final instar.

Observations on food are based on analysis of the contents of the entire gut from $10 \mathrm{LV}$, following the method of Cummins (1973). Food data were recorded on a percentage area basis using an eyepiece grid, and were classified under four categories: animal fragments, vascular plant pieces and filamentous algae, diatoms, and fine particulate organic material (FPOM) unidentifiable as to origin.

Location of specimens examined

CAS California Academy of Sciences, San Francisco

CNC Canadian National Collection, Biosystematics Research Institute, Agriculture Canada, Ottawa

DGD D. G. Denning, Moraga, California

DJB D. J. Burdick, Department of Biology, California State University, Fresno

INHS Illinois Natural History Survey, Champaign

LACM Los Angeles County Museum

MCZ Museum of Comparative Zoology, Harvard University, Cambridge 
NHA N. H. Anderson, Department of Entomology, Oregon State University, Corvallis

Oswood M. W. Oswood, Division of Life Sciences, University of Alaska, Fairbanks

SDS S. D. Smith, Central Washington University, Ellensburg

UA Strickland Museum, University of Alberta, Edmonton

UBC Spencer Entomological Museum, University of British Columbia

USNM National Museum of Natural History, Smithsonian Institution, Washington, D.C.

Vienna Naturhistorisches Museum, Vienna

Z.I. USSR Zoological Institute, Academy of Sciences, Leningrad

\section{Genus Onocosmoecus Banks}

Dicosmoecus (Onocosmoecus) Banks 1943, p. 357; type-species by original designation D. (O.) tristis Banks 1900.

Onocosmoecus: Schmid 1955, p. 37.

Onocosmoecus: Flint 1960, p. 19.

Onocosmoecus: Wiggins 1977, p. 268.

Onocosmoecus: Schmid 1980, p. 83.

Originally recognized as a subgenus of Dicosmoecus (Banks 1943), Onocosmoecus was later elevated to full generic status by Schmid (1955) on the basis of characters of adults. Larval characters added to the generic diagnosis by Flint (1960) were augmented by Wiggins (1977).

DesCription. Adults (Fig. 1) over-all light to medium brown colour, legs uniformly light brown; fore wings yellow-brown with variable markings, corneous spots in cells $\mathrm{R} 4$ and $\mathrm{M}$ variably pigmented from dark brown to colourless, variable darkish pigmented areas around these spots and along apical and costal margins, ranging from complete absence to the condition where most of the wing is medium brown; these corneous points and surrounding pigmented areas sometimes show a range of expression in a series from a single locality; hind wings paler and without markings. Venation similar to Dicosmoecus except discoidal cell of forewing not more than three times longer than basal radial sector (petiole). Length of fore wing: male $14.5-22 \mathrm{~mm}$; female $15-23 \mathrm{~mm}$. Tibial spurs $1,3,4$. Head and thorax with sparse brownish and pale setae; setal warts approximately same colour as surrounding cuticle; pleural setal 


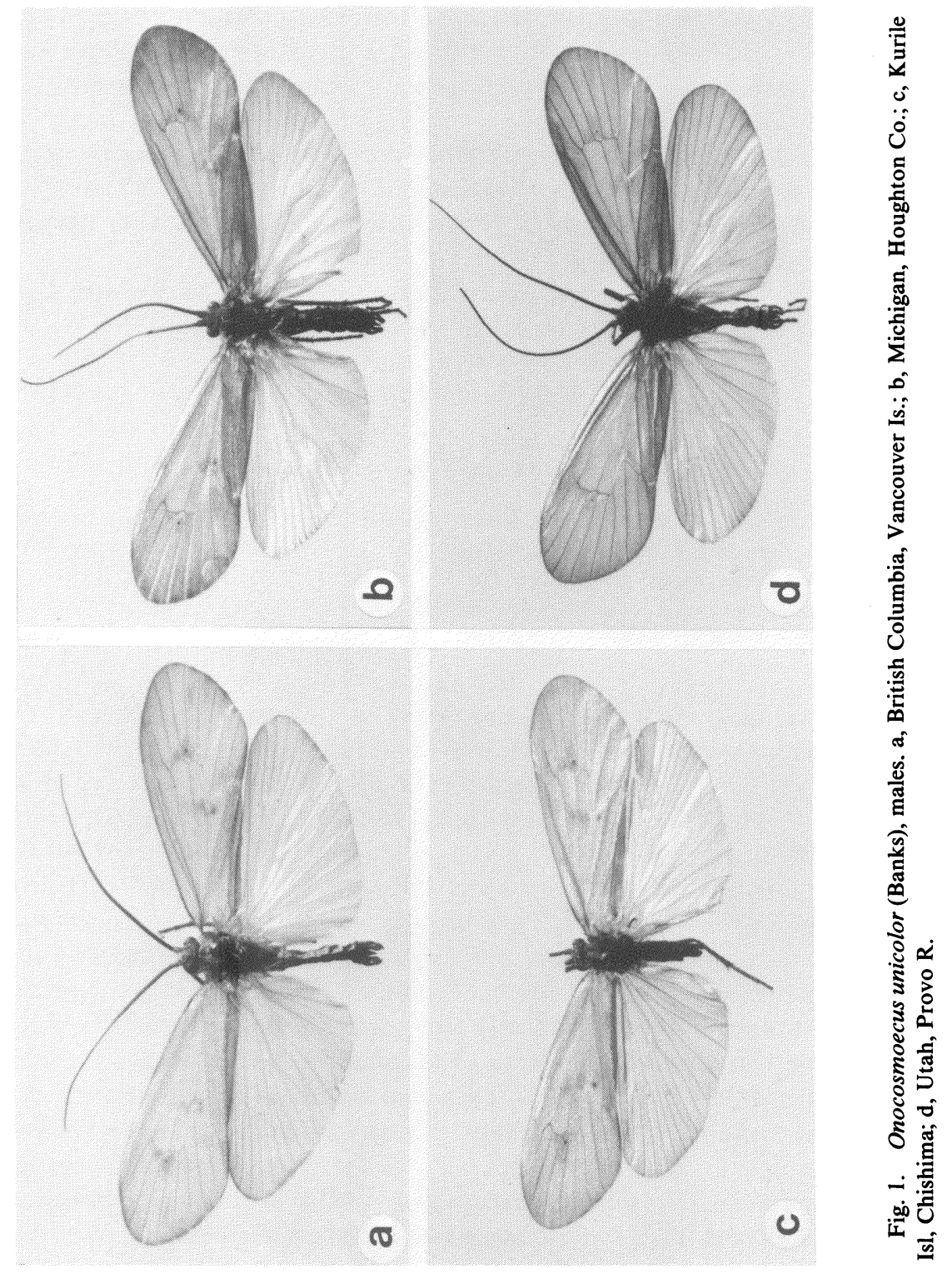


warts with pale setae, not as dense or long as in Dicosmoecus spp. (except D. obscuripennis Banks); mesepisternum lacking second setal wart.

Male genitalia (Figs. 2, 4, 11, 12). Segment IX broader laterally than in Dicosmoecus, sternum not extended posteromesally. Segment $X$ with external branches broad, flattened, longer than basal segment of inferior appendages, fused to segment IX close to middorsal line dorsad of internal branches; internal branches variably fused together dorsally, inferior branches lacking or occasionally represented by small process, or well developed and prominent; subanal plate cleft mesally, truncate apically. Phallus bearing pair of stout spines ventrally at base of aedeagus; parameres partially and variably fused with aedeagus, each expanded into membranous apex bearing 1-6 stout spines, the arrangement, number and length of these spines extremely variable and in more than 50 per cent of specimens examined spines differ on each paramere of a single individual.

Female genitalia (Figs. 3, 5, 6, 7, 13). Highly variable in structural detail. Segment VIII variably sclerotized ventromesally. Segment IX with massive rounded tergal lobes extending ventrolaterally to sternum IX which is here interpreted as reduced to a very small lobe or fold on each side of flattened vulval lobe; vulval lobe subdivided into three parts apically but continuous basally, median part variable in shape, lateral parts concave mesally and variable in shape. Segment $\mathrm{X}$ elongate, forming anal tube, open ventrally, variably cleft dorsomesally; in ventral aspect, basal shoulders of segment $\mathrm{X}$ highly variable in shape even within single series, frequently extended into angulate ledge or tooth at each side.

LARVA. (Fig. 8). Broad, light coloured median band extending from coronal suture, over pronotum and mesonotum; sclerites of head, pronotum and mesonotum with dense, minute spines. Pronotum lacking stout spines along anterior margin, but with row of 12-16 long, black setae just behind anterior margin, pair closest to mid-dorsal line distinctly shorter, space between these setae and next seta on either side narrower than that between remaining setae of row (character valid at least to LIII); pronotum and mesonotum with sparse, short yellowish and longer dark setae. Metanotal setae confined to setal areas, variable: sal 4-15, sa2 3-13, sa3 9-26; metepimera each with approximately $8-15$ setae. Setae on or near ventral 

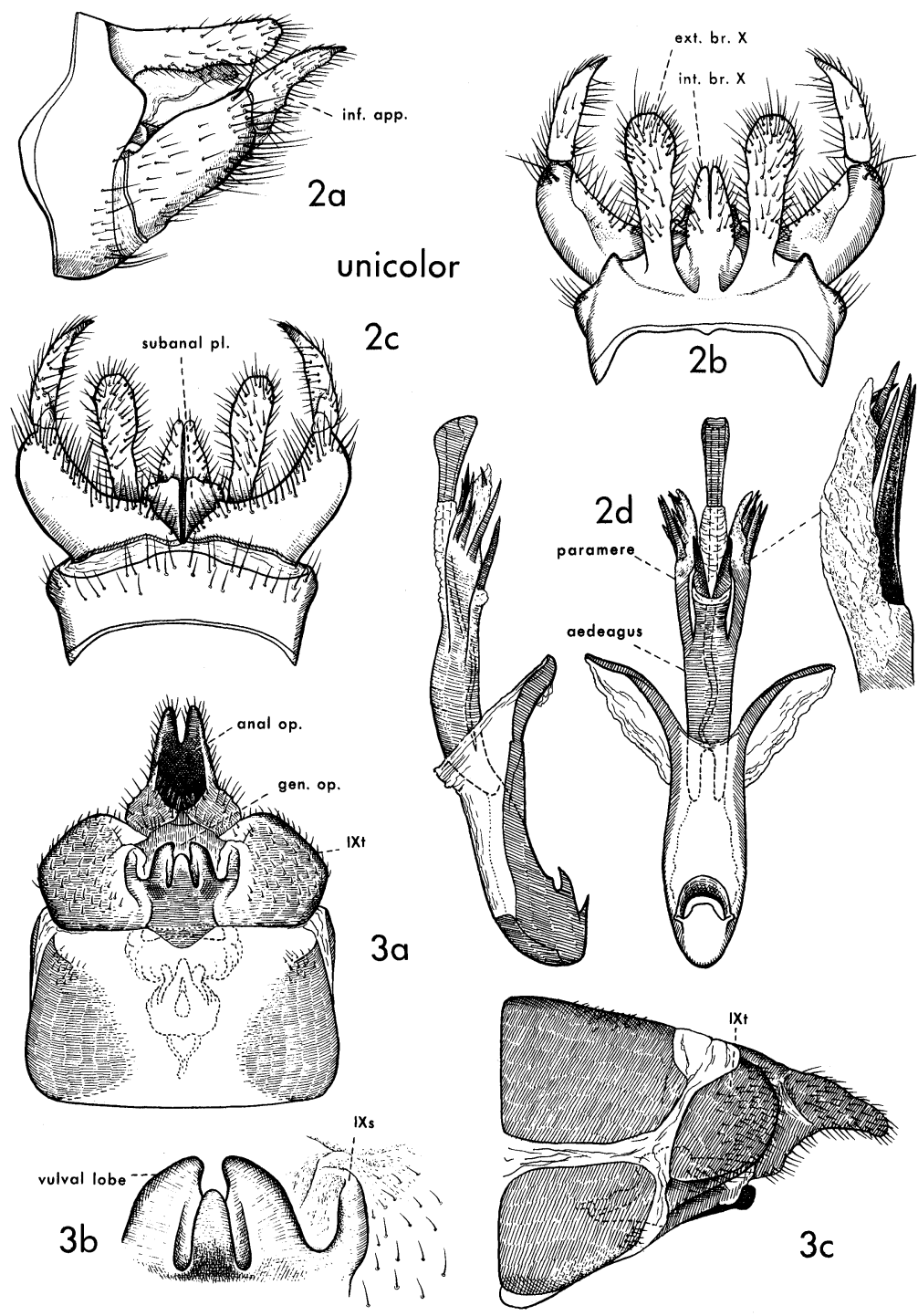

Figs. 2-3. Onocosmoecus unicolor (Banks). 2, Male genitalia (specimen from Ontario, Durham Co.): a, lateral; b, dorsal; c, ventral; d, phallus, lateral and ventral. 3, Female genitalia (specimen from Ontario, Durham Co.): a, ventral; b, detail of vulval lobe; c, lateral. (anal op., anal opening; gen. op., genital opening; IXt \& IXs, tergum and sternum of segment IX; inf. app., inferior appendage; ext. br. X, int. br. $X$, external and internal branches of segment $X$; subanal pl., subanal plate). 
edge of femora: profemur 1-3, mesofemur 4-11, metafemur 6-13; tibiae with a single pair of stout spur-like setae; trochanteral brush present on all legs, density variable. Femora flattened and compressed, ventral edges blade-like. Abdominal segment VI with 1-4 setae posterodorsally on each side of median line; VII with 1-5, usually 4 setae in this position; VIII with dorsal transverse row of approximately 16-24 setae; dorsal sclerite on segment IX with 12-15 setae; lateral abdominal gills present on segments IV and V; abdominal gills: dorsal, II 1-2, 3-4; III 3, 3-4; IV 3, 3-4; V 2-3, 2-3; VI 2-3, 2-3; VII 2, 2-3; VIII 0-2; lateral, II 0, 2-3; III 2-3, 2-3; IV 2-3, 2; V 1-2; ventral, II 2, 4; III 3, 4; IV 3, 3-4; V 2-3, 4; VI 2-3, 3-4; VII 2, 2-3. Length of larva up to $25 \mathrm{~mm}$.

CASE (Fig. 9). Constructed of fragments of leaves, wood and bark, walls rather thin and flexible; length of case up to $27 \mathrm{~mm}$.

PuPA. Generally as in Dicosmoecus with dorsal hook plates on segments III-VII, dorsal sclerites on segment I with pronounced median notch, and setal tufts present on first two antennal segments; dorsum of segment VIII with approximately 30 setae, dorsum IX with approximately 14; anal processes slightly curved.

\section{Onocosmoecus unicolor (Banks)}

Anabolia unicolor Banks 1897, p. 27; holotype , Washington, Mus. Comp. Zool. Harvard.

Asynarchus tristis Banks 1900, p. 254; cotypes 10̂, 2ㅇ, Colorado, Mus. Comp. Zool. Harvard. NEW SYNONYMY.

Dicosmoecus coloradensis Ulmer 1905, p. 64, figs. 14-16; cotypes 2 ô, 19, Colorado, Naturhistorisches Mus., Vienna. NEw Synonymy.

Anabolia quadrinotatus Banks 1908 (Anabolia 4-notata), p. 62, fig. 14; holotype $\hat{0}$, Newfoundland, Mus. Comp. Zool. Harvard. NEw SynONYmy.

Dicosmoecus flavus Martynov 1914, p. 253, cotypes 29, Kamchatka, Zool. Inst., Leningrad. NEW SYNONYMY.

Dicosmoecus (Onocosmoecus) occidentis Banks 1943, p. 362, figs. 104, 116, 124, 125, 128, 132, 136; holotype đ̂, Idaho, Mus. Comp. Zool. Harvard. New SYNONYMY.

Dicosmoecus (Onocosmoecus) alascensis Banks 1943, p. 363, figs. 105, 123, 129; holotype $\widehat{o}$, Alaska, Mus. Comp. Zool. Harvard. New Synonymy.

In 1943 Banks reviewed the characters used to distinguish the four Nearctic species then assigned to $D$. (Onocosmoecus), and at the same time described two additional species, D. (O.) occidentis and $D$. (O.) alascensis. After studying more than 1000 adult specimens, 
we conclude for reasons outlined below, that all of these names are best treated as synonyms of the original species $O$. unicolor; also included in the synonymy is the Palaearctic $O$. flavus.

In distinguishing species within the unicolor complex, Banks (1943) utilized characters derived from colour of the fore wings and genitalic morphology. The corneous points on the fore wings of most Trichoptera in cells R4 and M (thyridial cell) are usually darkly pigmented in species of Onocosmoecus and contrast strongly with the light to medium brown fore wings. Around these points the membrane often has indefinite darkened areas, and the extent of these "clouds" was used by Banks as a diagnostic character (Fig. 1). Although the darkened areas show some differences among type series, we found that variation prevented their use as effective diagnostic characters. We have been unable to find in genitalic structures of either males or females throughout the unicolor complex discrete or discontinuous character states signifying genetic groups and taxonomic species. Differences in shape of the branches of segment $\mathrm{X}$ or segments of the inferior appendages to which Banks (1943) also referred seem valid for a few male specimens but blend into a seemingly continuously variable range when more series are studied. Particular importance as diagnostic characters was given by Banks to the number and arrangement of spines on the parameres. We found inordinate variability in these spines, ranging from one to six on each paramere throughout the range of the unicolor complex and frequently with a range in number exhibited within a series from one locality; size and arrangement of the spines was equally variable. Frequently on the two parameres of a single individual the spines differed in both number and arrangement, sometimes exhibiting conditions said to be diagnostic for two of the putative species.

Diagnosis of the females was based mainly on characters of the shape of the tapered posterior extremity of segment X (Banks' sheath of the ovipositor) and presence of a basolateral tooth or ledge, and shape of the three parts of the vulval lobe. Using these features Banks characterized the females in rather general terms but not with precise diagnoses. We found, as with the males, that because of many intermediate conditions in the characters proposed we were unable to establish discrete groups for females within the unicolor complex.

We have been cognizant of the possibility that species might be definable within the unicolor complex on the basis of other 


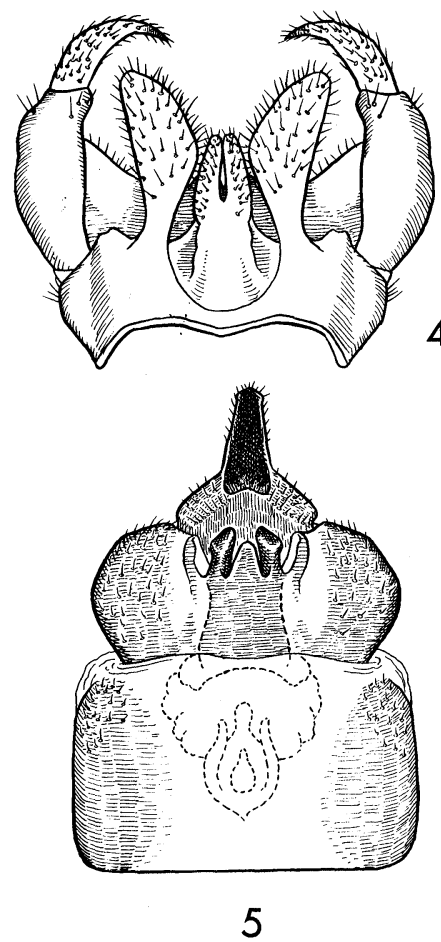

$4 a$
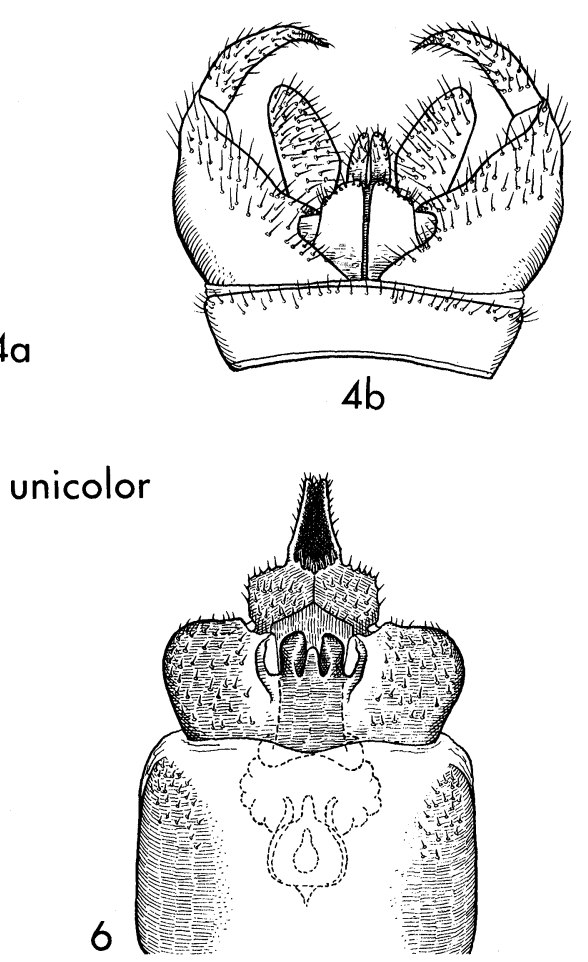

Figs. 4-6. Onocosmoecus unicolor (Banks). 4, Male genitalia (specimen from Alaska, Admiralty Is.): a, dorsal; b, ventral. 5, Female genitalia (specimen from Alaska, Admiralty Is.), ventral. 6, Female genitalia (specimen from Oregon, Baker Co.), ventral.

characters, including those from other body structures, but we have not been able to recognize discontinuities in any other characters. Thus we conclude from our study of this material that the entire unicolor complex is best treated as a single, variable taxonomic species. Conclusions from study of the type specimens of the species placed in synonymy follow.

O. unicolor (Banks). We have examined the holotype female (Skokomish R., Washington) in the Museum of Comparative Zoology. The wings are torn and the apical lobes of segment $\mathrm{X}$ broken. The two corneous points on the fore wing are only lightly pigmented, and the surrounding membrane only slightly darker than 
the rest of the wing. Banks (1943) stated that the apical lobes of segment $\mathrm{X}$ are longer in $O$. unicolor than in the other species; in females of the unicolor complex that we have examined these lobes are elongate but variable, and discontinuously longer in none. In the holotype there is a distinct tooth or ledge at the base of each lobe of segment $X$ on the lateral margin (e.g. Fig. 6); expression of this character also shows continuous variability in our material and the ledge is lacking in most specimens (e.g. Fig. 3a). The median and lateral vulval lobes of the holotype taper to rounded points, which blend continuously with a range of conditions in our material.

The male has not been clearly identified in the literature. The illustration of male genitalia labeled as unicolor by Ross (1938, fig. 48) was given only the status of the "supposed male of 'unicolor" by Banks (1943); and although no locality data were given for the specimen illustrated by Ross, Banks (1943: 364) stated that it came from Inyo Co., California. Banks himself (1943) referred to specimens from Banff and Alaska that "may be males of this species," offering as a diagnostic character that the third and fourth spines of the paramere are not widely separated. Our material shows such a very wide range of variation in arrangement of the spines of the parameres that this character cannot be regarded as distinctive.

$O$. tristis (Banks). We have examined the three specimens (South Park, Colorado) in the type series from the Museum of Comparative Zoology. From these specimens Ross (1938) designated a lectotype male (17 Aug. 1899) and lectoallotype female (20 Aug. 1899); the remaining female (20 Aug. 1899) is identical to the lectoallotype. Ross (1938) placed $O$. tristis in synonymy with $O$. unicolor, but Banks (1943) maintained that the two were distinct species. Although the females in the type series were characterized by a pronounced basolateral tooth or ledge on segment X (Banks 1943), there seems little difference between these specimens and what remains of this character in the holotype of $O$. unicolor (see above). The apices of the posterior lobes of segment $X$ are closely appressed in both females of the type series, and all three parts of the vulval lobe are truncate. This latter character contrasts with somewhat more rounded lobes in the holotype of $O$. unicolor, but we have many specimens showing intermediate conditions. The male in the type series of $O$. tristis was distinguished by narrower external branches of segment X (superior appendages of Banks), but 

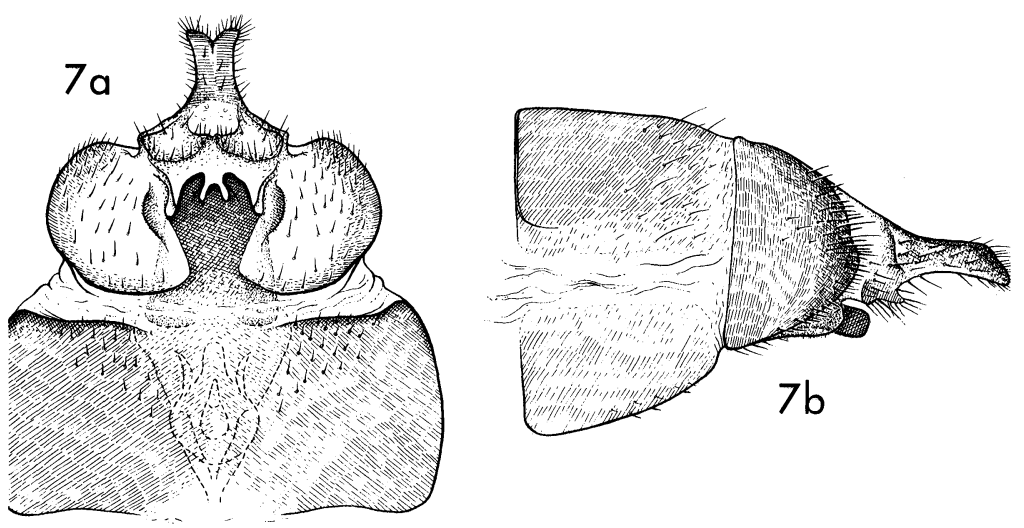

Fig. 7. Onocosmoecus unicolor (Banks), female genitalia (specimen from Kamchatka, U.S.S.R.; Syntype of $O$. flavus (Martynov)): a, ventral; b, lateral.

we find little distinction in this character and considerable variation in our material generally (cf. Figs. 2 and 4). The five spines of the parameres, offered as a diagnostic character for $O$. tristis by Banks, have little value in view of the wide variability in number, size and arrangement in our material of the unicolor complex. The three specimens in the type series show slightly different degrees of pigmentation of the corneous points of the fore wing.

Although Ross (1938) designated both lectotype male and lectoallotype female for $O$. tristis, there is no male specimen bearing a lectotype label, and it must be concluded either that the specimen was not labelled, or that the label or labelled specimen has been lost. Since among the three remaining specimens of the type series there is only one male, that specimen is here designated lectotype, an assignment which would of course lapse should Ross' lectotype be found.

O. coloradensis (Ulmer). In the original description Ulmer offered no diagnostic characters for separating $O$. coloradensis from closely related forms, but he later commented in a re-description of O. flavus (Ulmer 1927: 6) that his $O$. coloradensis was the same as Asynarchus tristis Banks, the genital appendages resembling in turn those of $O$. flavus Martynov. Diagnosis on the basis of only two spines on each paramere was later proposed by Banks (1943), who 


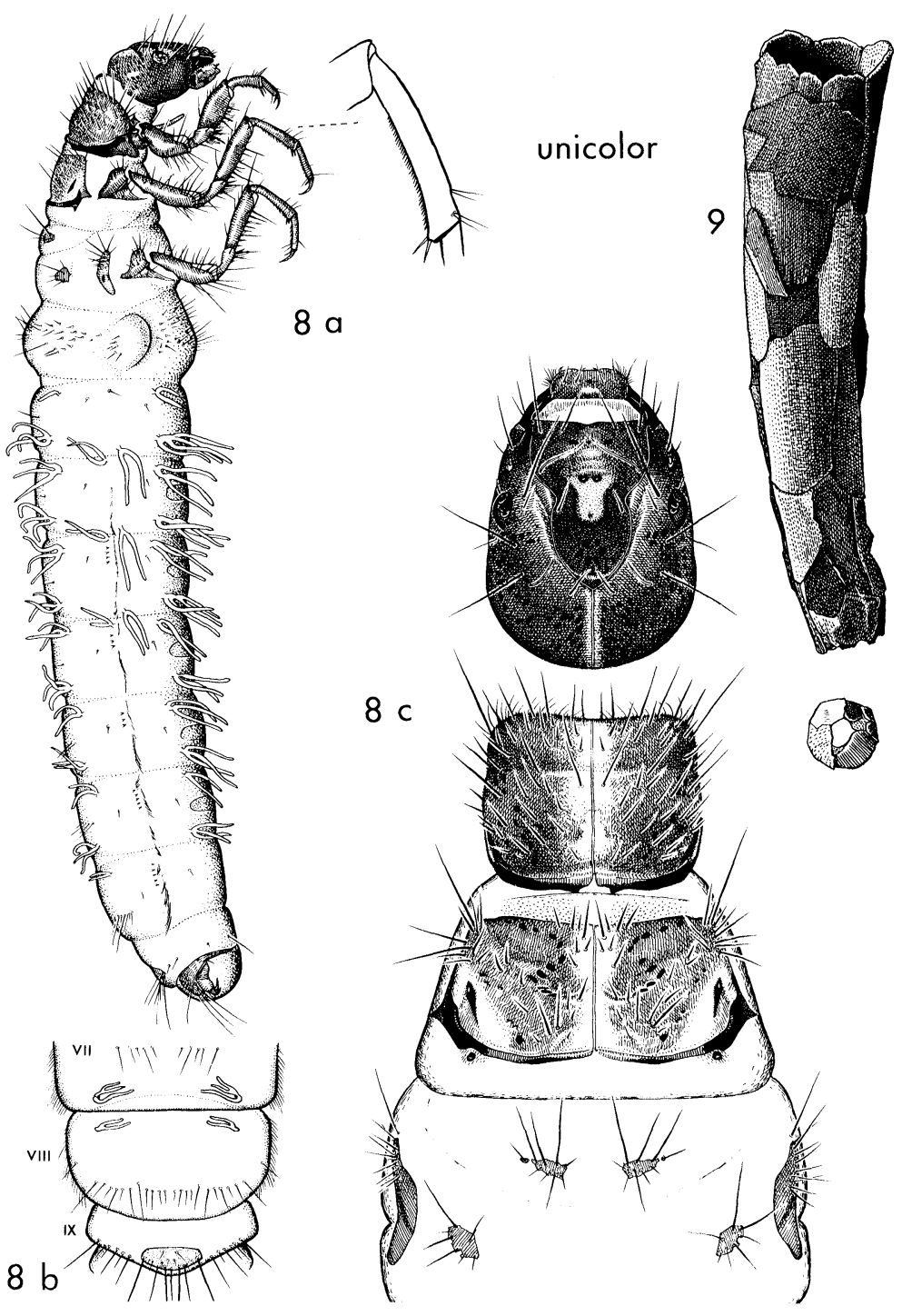

Figs. 8-9. Onocosmoecus unicolor (Banks), larva (specimen from British Columbia). 8a, larva with detail of mesofemur, lateral; $b$, abdominal segments VII, VIII, IX, dorsal; c, head and thorax, dorsal. 9, case, detail of posterior end. 
cited an illustration by Ross $(1938$, fig. 48$)$ as an example. It is not clear what basis there was for this character; no reference was made to it in Ulmer's original description (no genitalic preparations had been made from the type series), and Ross' figure actually shows a third small apical spine on the paramere. Origin of the specimen on which Ross' figure 48 was based was not given, although Banks (1943: 364) stated that it came from Inyo Co., California; furthermore, although designated as $O$. unicolor by Ross, the specimen was not accepted by Banks as the male of that species (see above), evidently because he regarded it as $O$. coloradensis.

We have examined the three co-types $(2 \hat{\sigma}, 1$,, S. Colorado, 1879) in the collection of the Naturhistorisches Museum, Vienna. The parameres of one male each have three spines and those of the other, four spines. We find no other features of these males that are distinctive. In the female of the type series, the apical lobes of segment $\mathrm{X}$ are rather long and slender, lacking the basal ledge or tooth of the holotype of $O$. unicolor or the females in the type series of $O$. tristis. The two corneous points in the fore wing are dark in all specimens, which in the males particularly are surrounded by a relatively large dark area.

O. quadrinotatus (Banks). We examined the holotype male (Grand Lake, Newfoundland, 28 July 1906) in the Museum of Comparative Zoology. This is the only name based on material from eastern North America, and was distinguished from the western forms by uniformly dark fore wings (Banks 1943). The holotype displays this character, but in some eastern populations there is a tendency for slighty darkening around the spot in cell R4 (Fig. 1b). Moreover, some specimens from western North America also have uniformly dark fore wings, e.g. Fig. 1d. Some of these have several spines on the parameres (e.g., California, Nevada Co., Sagehen Cr., 4 Aug. 1985, 1ठ, ROM), but in others the spines are reduced to one or two (Utah, Summit Co., E. Fork Bear R., ca. 2 mi. above confluence with Bear R., 4-5 Aug. 1985, 7 ô, ROM; Idaho, Teton Co., Darby Cr., 6-7 Aug. 1985, 60̄, ROM). The holotype male has five and six spines respectively on the two parameres, distinguished by the basal spine being little longer than the others and not reaching the tip of the paramere (Banks 1943). Within the eastern part of North America where no western species has ever been recorded in the literature, we found spines of the parameres 
ranging from three to six, with the basal spine in some extending to the end of the paramere; and within a single series (Province of Quebec, Wacouno R., n. Sept. Iles, 10 Aug. 1973, ROM) all conditions from three to six are represented.

No precise diagnosis was offered for the female by Banks, but only the general characters of rather short apical lobes (Banks' sheath of the ovipositor) and absence of a basal ledge on segment X, and a broad median vulval lobe (Fig. 3). Our sample of females from eastern populations comprises only six specimens (Ont., P.Q., N.H., Mich.), but genitalic structures differ considerably among them: shape of the vulval lobes, and on segment $X$, the length and taper of the apical lobes and development of the basolateral ledge. These variations concern the same characters proposed by Banks for diagnosis of the western species of Onocosmoecus, and we find no other basis for identification of $O$. quadrinotatus as a separate species.

$O$. occidentis (Banks). We examined the holotype male (Wallace, Idaho, 1 October) in the Museum of Comparative Zoology. Diagnosis was based solely on genitalic characters. In the male the internal branch of segment X (Banks' superior plate) was said to be broadened toward the base and to have a median separation extending to the basal fourth; our examination of the holotype reveals no distinctive broadening in the shape of these combined internal branches and the median separation extends no more than half the length, which is generally characteristic of males of the unicolor complex. Spines of each paramere are four in number as stated, but the arrangement attributed to them holds true only for one paramere of the holotype, spines of the other being quite different. The female was distinguished by characters of segment $\mathrm{X}$-short apical lobes with slightly divergent tips and lacking the basolateral tooth or ledge; over the range of characters in O. unicolor s.l. none of these characters is unique as described, and we find nothing that would serve to distinguish this species.

O. alascensis (Banks). We have examined the holotype male (1 Aug. 1917) and single male paratype (29 July 1917), both from Iditarod, Alaska, from the collection of the Museum of Comparative Zoology. Among the diagnostic characters proposed by Banks (1943) was four spines on the parameres, which the holotype has, but the paratype has three and five spines respectively on the two 
parameres. The external branches of segment $X$ (superior appendages of Banks) are slightly narrowed at the base, but this feature is variable and appears not to be of diagnostic value. The two corneous points on the fore wings are darkly pigmented and each is surrounded by a fairly well defined dark area. Within the material of the unicolor complex that we have examined none of these characters is distinctive, and we find no reliable basis for identifying this species.

O. flavus (Martynov). Recognition of this Palaearctic species was somewhat irregular in that the description of the female appeared as Dicosmoecus sp. (sp.n.?) (Martynov 1913: 477), with the name proposed later (Martynov 1914: 253). To the original description, Martynov (1913: 478) added the comment: "This species resembles $D$. unicolor Banks from Washington Territory. But having seen no specimens of the last named species, and the structure of its genital appendages being entirely unknown, I cannot identify my specimens with $D$. unicolor." Judging by the illustrations, the female appears to have been described again as Dicosmoecus sp. (Martynov 1925, figs. 1, 2). The male was described and illustrated by Ulmer (1927) along with the female; Ulmer mentioned the surprising similarity between flavus and the North American coloradensis [ = unicolor $]$ which he had described earlier. We have examined from the Zoological Institute, Academy of Sciences, Leningrad, one of the two female syntypes (Pushino, Kamchatka R., 19 July 1908) and a male evidently identified by Martynov; and in the ROM are additional specimens from two localities in Kam-

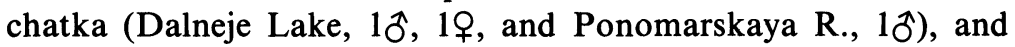
from the Kurile Islands (Chishima, 1§) (Fig. 1c). The syntype female (Fig. 7) fits readily into the range exhibited by our Nearctic material, and we found no unique genitalic characters; the dorsal lobes of segment $\mathrm{X}$ lack a basolateral tooth and the median vulval lobe is narrow and well separated from the lateral lobes. In genitalic characters this flavus syntype is very close to females from Washington (Olympic National Park, 29 June-1 July 1969, ROM \#690148) and from the Yukon (Dempster Hwy., km. 72, 1 Aug 1979, ROM \#791191b); other Washington females (Minotaur Cr., Chelan Co., Sept.-Oct. 1976, S. D. Smith coll.) have several similar characters. By contrast, in the Dalneje Lake female, segment $\mathrm{X}$ has a basolateral tooth and the median vulval lobe is broad with its sides largely 


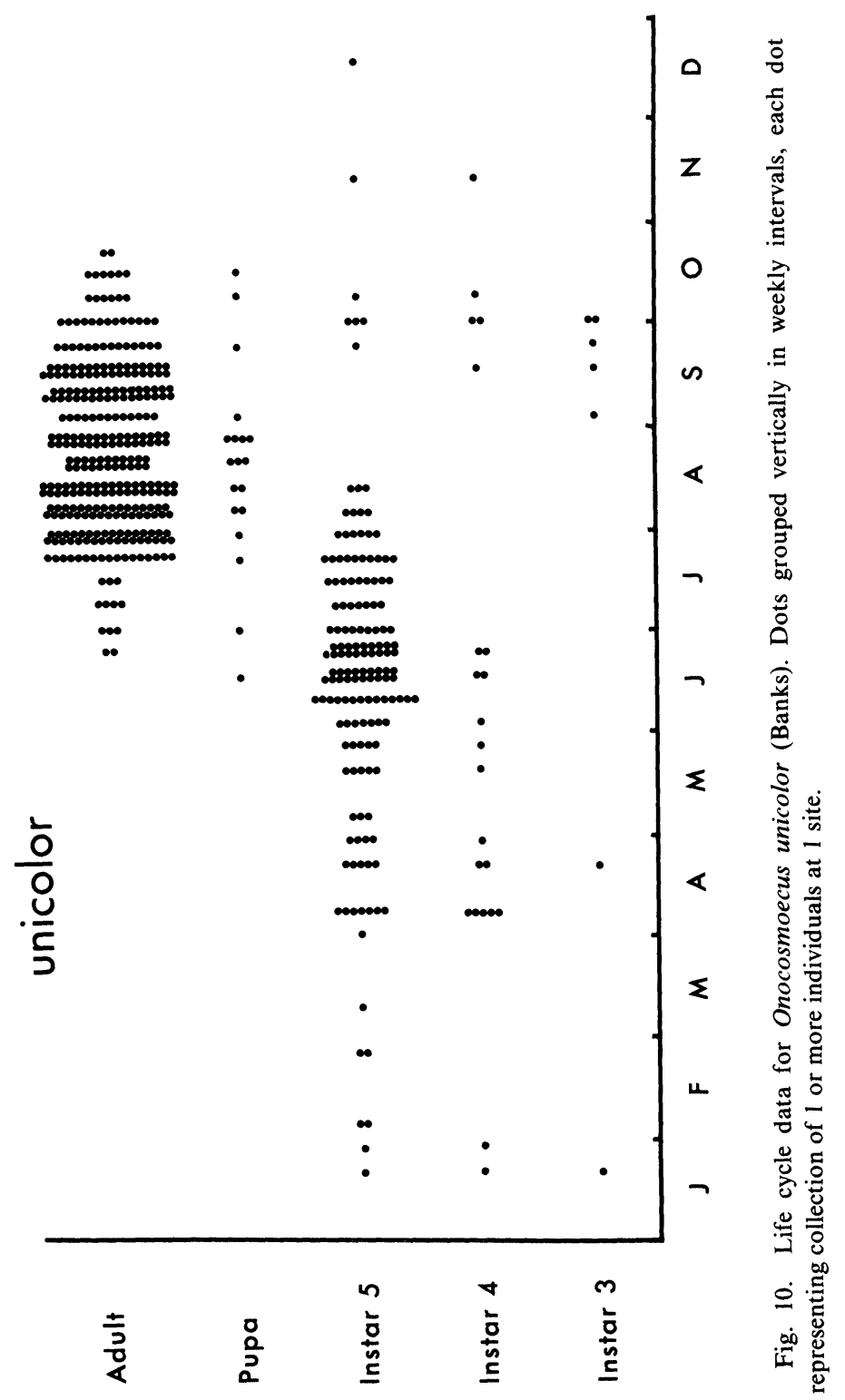


fused to the lateral lobes, demonstrating a tendency for variation similar to that which is so widespread among Nearctic specimens. All four male specimens are generally consistent in genitalic characters with the external branches of segment $X$ expanding rather broadly at mid-length and tapering toward a rounded apex, but this condition also occurs widely in Nearctic material; two of the specimens have four spines on each paramere, but the Dalneje Lake male shows three and five spines respectively on each paramere, and the Chishima male five and six spines. The fore wings of the syntype female have dark corneous points surrounded by faint darkish areas of moderate size, similar to the type specimens of the Nearctic $O$. occidentis, alascensis, and coloradensis; and these darkish areas are somewhat variable in size in the other specimens. The few specimens we have seen are smaller [length of fore wing male 14.5-16 mm ( $\mathrm{n}=$ 4), female 15-17.5 $(n=2)]$ than most of our North American specimens, although specimens of that size are represented in our material. Finding no characters to separate these representatives of $O$. flavus from the Nearctic populations of $O$. unicolor, we extend our interpretation of $O$. unicolor as a widespread and highly variable species to include the Palaearctic $O$. flavus.

Other variants. One of the extreme variants encountered occurs in Alaska (Admiralty Island, Young Bay, 23 July 1981, 1ð, 1웅 ROM). The male of this series (Fig. 4) shows both pronounced narrowing at the base of the external branch of segment $X$ and broadening toward the apex, as well as a strong tooth on the mesal edge of the basal segment of the inferior appendage (Fig. 4b). In the female (Fig. 5), segment $X$ forms a slender tubular ovipositor lacking any dorsomedian subdivision, and the basal shoulders of $\mathrm{X}$ are not produced as a ledge. By contrast, in a female from Oregon (Baker Co., Pine Cr., 14 July 1967, 1ð^, 19, ROM), segment X has the form of a slender ovipositor (Fig. 6), but the base of $\mathrm{X}$ is strongly produced as a sharp dentate ledge. While these are representative of the extreme variation, we found intermediates between them and less extreme genital structures. In a single series from Oregon (Lane Co., $12 \mathrm{mi}$. SE Eugene, 22 Sept. 1968, 2ðૌ, 2우, ROM) segment $\mathrm{X}$ in ventral aspect of one female forms an elongate ovipositor similar to that in Figure 5, but in the other female the ovipositor is extremely wide; in one of these females the lateral vulval lobes are enlarged apically into a thick truncate knob, very unlike the more usual flattened condition in Figure $3 \mathrm{~b}$. 
Diagnosis for adults of $\mathrm{O}$. unicolor (Banks) s.l. Fore wings ranging in colour from light yellow brown to dark brown; length of fore wing: male $14.5-18.5 \mathrm{~mm}$; female $15-21 \mathrm{~mm}$.

Male genitalia (Figs. 2, 4). Segment IX not unusually short; inferior appendages variable in shape of segments, ventromesal angle of basal segment in ventral aspect ranging from obtuse (Fig. 2c) to sharply pointed (Fig. $4 b$ ). Segment $X$ with external branches tending to be orientated in an oblique to horizontal plane, usually narrowed basally and broader toward the apex; internal branches fused together into a flattened, somewhat pointed median lobe variably cleft at the apex; inferior branches usually absent, occasionally represented by a small protuberance or angulate vertical lobe. Phallus with parameres variably fused to aedeagus, ranging from little separation (Fig. 2d) to almost complete separation (as in Fig. 11d); spines at apex of parameres extremely variable, ranging from 1 to 6 , usually straight and singlepointed.

Female genitalia (Figs. 3, 5, 6, 7). Segment IX with enlarged tergal lobes uniformly bulbous; sternum IX reduced to a small sclerotized lobe at each side of the vulval lobe. Segment $X$ in ventral aspect tapered and tubular, broadly open ventrally, dorsally entire or with a narrow median cleft, base of $\mathrm{X}$ extended into a lateral shoulder in ventral aspect, variable in shape and frequently dentate.

Biology. Larvae of $O$. unicolor live in slow water and pool areas of cool rivers and streams, and also in the littoral zone of cool lakes. There appears to be little preference in substrate since larvae occur in stony streams and organic sediments of lake margins. Larvae usually burrow into bottom sediments for pupation, fixing the case to some larger object such as a rock. Collection records plotted by week for specimens examined (Fig. 10) are interpreted as a univoltine life cycle. Most adults emerge in the period 15 July-15 September. Early larval development proceeds quickly, third instars appearing at least by early September, fourth instars by midSeptember, with fourth and fifth instars overwintering. In contrast to Dicosmoecus (Wiggins \& Richardson 1982, figs. 33, 34), no diapausing fifth instar larvae were found in $O$. unicolor. Pupae were collected from June to the middle of October. These data are similar to those from an intensive study of a population in Marion Lake, B.C. (Winterbourn 1971), except that most larvae overwintered there as instars III and IV; egg masses (4.5-5 mm diam., approx. 150 eggs each) were found 9-24 September. 
Larvae are shredders, vascular plant pieces and filamentous algae combined accounting for over $71 \%$ of the total gut content in material $(10 \mathrm{LV})$ we sampled. Animal fragments averaged $9.7 \%$ but in one individual accounted for $97 \%$ of the gut content. Diatoms were present in small numbers in most guts, averaging $12.2 \%$, although one specimen contained approximately 77 percent diatoms. Fine particulate organic matter averaged $6.9 \%$. Our data contrast strongly with those of Winterbourn (1971) who reported only sediment and animal fragments in the guts of this species in a lake habitat.

Head widths for the last three instars have been established as follows $(\mathrm{n}=204)$ : $\mathrm{LV}, 1.62 \mathrm{~mm}$ (range 1.25-2.0); LIV, $1.12 \mathrm{~mm}$ (1.025-1.125); LIII, $0.725 \mathrm{~mm}$.

Range. (Fig. 14). As defined here, O. unicolor is transcontinental through northern North America, extending throughout the western mountains and into eastern Asia. In North America the species is recorded from Alaska, Alberta, British Columbia, California, Colorado, Idaho, Maine, Manitoba, Massachusetts, Michigan, Montana, Nevada, Newfoundland, New Hampshire, New Mexico, New York, Northwest Territories, Nova Scotia, Ontario, Oregon, Quebec, Saskatchewan, South Dakota, Utah, Vermont, Washington, Wisconsin, Wyoming, and Yukon.

Material examined and other records. ALASKA. 24 June-27 September. Mile 140, Hwy. 3 (CNC). Admiralty Is. (ROM). Anchorage (ROM). Angel Cr. (ROM). Bear Cr. (CNC). Byers Cr. (ROM). Chatanika R. (Oswood). Chena R. (Oswood). Chichagof Is. (ROM). Chilkoot R. (ROM). Circle (ROM). Delta (CNC). Eklutna Lk. (INHS). Etolin Is. (ROM). Fairbanks (CNC). Glenallen (ROM). Gulkana R. (ROM). Haines (ROM). Hood Bay Cr. (ROM). Iditarod (MCZ, USNM). Juneau (ROM). Kenai Peninsula (ROM). Kodiak Is. (ROM). Lk. Iliamna (ROM). Lowe (Oswood). Lower Summit Lk. (ROM). Moon Lk. (ROM). Palmar (USNM). Parks Hwy., mp. 128.5 (ROM). Port Heiden (ROM). Portage (CNC). Prince of Wales Is. (DGD). Reflection Lk. (ROM). Sadlerochit Spring (USNM). Squirrel Cr. Cpgrd. (CAS, DGD). Steese Hwy., ml. 35-97.2 (ROM). Tolsona R. (ROM). Trapper Cr. (CNC). Turner Lk. (ROM). Ugak Bay (ROM). Umnak Is. (ROM). Upper Gulkana R. (INHS). Wasilla (INHS). Wrench Cr. (ROM). ALBERTA. 16 July-12 October. Banff (INHS, ROM, UA, USNM). Calgary (INHS). Canmore (ROM, UA). Coleman (UA). 
Crowsnest R. (UA). Cypress Hills Prov. Pk. (ROM). Dungarvan Cr. (ROM). Edson (ROM, UA). Fairview (ROM). Fawcett (UA, USNM). Ft. McMurray (USNM). Ft. Vermilion (ROM). Galwey Brook (ROM). Gorge Cr. (UA). Hinton (UA). House R. (ROM). Jasper Nat. Pk. (ROM, UA). Kananaskis (UA). LaBiche R. (ROM). Longview (UA). Lundbreck Falls (ROM, UA). McLeod R. (UA). Nojack (ROM, UA). Nordegg (ROM, UA). N. Ram R. (ROM). Red Deer Crossing (ROM). Sheep R. (UA). Ware Cr. (UA). Waterton Nat. Pk. (ROM, UA). Whitecourt (ROM). Wildhorse Camp (ROM). Yara Cr. (ROM). BRITISH COLUMBIA. 2 July-14 November. Atlin (CNC). Babine R. (INHS). Beaverdell (CNC). Cassiar Jct. (CNC). Clinton (ROM). Creston (CNC). Cultus Lk. (CNC, INHS, ROM). D’Arcy (ROM). E. C. Manning Prov. Pk. (ROM). Edgewood (INHS). Fernie (INHS, ROM). Fraser Lk. (CNC). Galena Bay (CNC). Glacier (ROM). Golden (ROM). Haney (ROM). Harrison Lk. (CNC, INHS). Highland R. Prov. Pk. (ROM). Invermere (ROM). Jesmond (CNC). Kamloops (ROM). Knutsford (ROM). Langley (ROM). Lillooet (CNC, USNM). Little Fort (CNC). Lower Post (CNC). McBride (CNC). Miledge Cr. (CNC). Mt. Robson Prov. Pk. (ROM). New Denver (CNC). Nicola (CNC). Pemberton (CNC). Princeton (CNC). Prophet R. Prov. Pk. (ROM). Queen Charlotte Islands (USNM). Revelstoke (USNM). Rolls (INHS). Rosebery (CNC). Salmon Arm (INHS). Sandon (USNM). Sicamous (CNC). Squamish (CNC). Stanley (CNC). Summerland (CNC). Terrace (CNC, INHS, USNM). Topley (CNC). Trutch (CNC). Valemount (CNC). Vancouver (INHS). Vancouver Is. (CNC, ROM). Vavenby (USNM). Walhachin (ROM). Wycliffe (ROM). Yellowhead Pass (ROM). CALIFORNIA. 23 July.-11 October. Alpine Co. (INHS). Fresno Co. (DJB). Inyo Co. (DJB, INHS). Modoc Co. (CAS, CNC, USNM). Napa Co. (ROM). Nevada Co. (ROM). Placer Co. (DGD, LACM). Plumas Co. (DJB). Santa Cruz Co. (INHS). Sequoia Nat. Pk. (INHS). Siskiyou Co. (CAS, USNM). Trinity Co. (CNC). Yosemite Nat. Pk. (LACM). COLORADO. 2 August-1 October. Cameron Pass (INHS). Chaffee Co. (CAS). Custer Co. (USNM). El Paso Co. (INHS). Jefferson Co. (USNM). Larimer Co. (INHS, ROM). Park Co. (USNM). Routt Co. (CAS). Saquache Co. (ROM). S. Colorado (Vienna). S. Park (MCZ). IDAHO. 5 July-1 October. Bannock Co. (ROM). Bonner Co. (CAS, ROM). Idaho Co. (ROM, 
USNM). Latah Co. (ROM). Teton Co. (ROM). Valley Co. (CAS, ROM). Wallace (MCZ). MAINE. 4 August-15 September. Cumberland Co. (USNM). Oxford Co. (INHS). Piscataquis Co. (USNM). MANITOBA. 27 August. Flin Flon (ROM). God's R. (ROM). Hayes R. (INHS). MASSACHUSETTS. No adults. Berkshire Co. (USNM). MICHIGAN. 28 August-29 August. Emmet Co. (ROM). Houghton Co. (ROM). Lake Co. (fide Flint 1960). MONTANA. 7 August-28 September. Carbon Co. (ROM). Cascade Co. (ROM). Flathead Co. (ROM). Gallatin Co. (CNC). Glacier Nat. Pk. (DGD, ROM, USNM). Missoula Co. (INHS, ROM). Ravalli Co. (ROM). NEVADA. 31 July. Washoe Co. (USNM). NEWFOUNDLAND. Grand Lake, 28 July, (MCZ). Cartwright (Labrador) 2 August (ROM). NEW HAMPSHIRE. 4 August-10 September. Coos Co. (INHS, ROM, USNM). NEW MEXICO. 4 September. Rio Arriba Co. (INHS). NEW YORK. 7 September. Ulster Co. (INHS). NORTHWEST TERRITORIES. 6 July-24 August. Aklavik (CNC, ROM). Great Slave Lk. (UA). Norman Wells (ROM). NOVA SCOTIA. 12 August, Baddeck (fide Banks 1943). ONTARIO. 9 August-18 September. Algoma Dist. (ROM). Belfountain (ROM). Cochrane Dist. (ROM). Durham Co. (ROM, USNM). Kenora Dist. (ROM). Lk. Superior (ROM). Midland (ROM). Oro Station (ROM). Rainy R. Dist. (ROM). Thunder Bay Dist. (ROM). Wellington Co. (ROM). OREGON. 21 June-13 November. Baker Co. (ROM, USNM). Benton Co. (INHS, NHA, ROM). Blue Mtns. (ROM). Clackamas Co. (ROM). Clatsop Co. (INHS, ROM, USNM). Crook Cr. (ROM). Deschutes Co. (NHA, ROM). Douglas Co. (ROM). Grant Co. (ROM). Harney Co. (ROM). Hood River Co. (ROM). Jefferson Co. (ROM). Klamath Co. (NHA). Lake Co. (DGD, ROM). Lane Co. (ROM). Lincoln Co. (DGD, ROM). Linn Co. (ROM). Umatilla Co. (ROM). Union Co. (NHA, SDS). Wallowa Co. (INHS, NHA, ROM). Wasco Co. (ROM). Wheeler Co. (ROM). Yamhill Co. (INHS). QUEBEC. 29 June-23 September. Brebeuf (ROM). Cascapedia (INHS). Harrington (ROM). Matamek R. (fide Williams and Williams 1979). Mt. Lyall (INHS). Wacouno R. (ROM). Other records fide Roy and Harper 1979. SASKATCHEWAN. 22 August-2 September. N. Battleford (ROM). Pierceland (ROM). Prince Albert (INHS, ROM). SOUTH DAKOTA. No adults. Lawrence Co. (ROM). U.S.S.R. 19 July-17 September. Kamchatka (ROM). Kurile Islands, 
Chishima (ROM). Pushino (Z.I. USSR). UTAH. 23 July-16 September. Cache Co. (INHS, ROM). Carbon Co. (USNM). Daggett Co. (ROM). Garfield Co. (ROM). San Juan Co. (USNM). Summit Co. (CAS, ROM, USNM). Wasatch Co. (INHS, ROM). Washington Co. (USNM). VERMONT. 11 September-23 September. Bennington Co. (ROM). Windham Co. (DGD). WASHINGTON. 1 June-9 October. Chelan Co. (ROM, SDS, USNM). Jefferson Co. (ROM, USNM). King Co. (ROM). Kittitas Co. (ROM, SDS, USNM). Mt. Rainier Nat. Pk. (ROM). Okanogan Co. (USNM). Pacific Co. (ROM). Snohomish Co. (MCZ). Whatcom Co. (CNC, ROM, USNM). Whitman Co. (INHS). Yakima Co. (ROM). WISCONSIN. (fide Longridge and Hilsenhoff 1972). WYOMING. 6 August-1 September. Albany Co. (ROM). Carbon Co. (ROM). Teton Co. (INHS). Uinta Co. (USNM). Yellowstone Nat. Pk. (INHS). YUKON. 26 June-29 August. Alaska Hwy. At Aishihik R. (CAS) and at Koidern R. (ROM). Bearfeed Cr. (ROM). Blackstone (ROM). Burwash Landing (CNC). Champagne (CNC). Christmas Cr. (ROM). Clear Cr. (ROM). Dawson (CNC). Dempster Hwy., kmp 72, 140.5 (ROM). Dezadeash Lk. (ROM). Eagle Plain (ROM). Eagle R. (ROM). Engineer Cr. (ROM). Flat Cr. (ROM). George's Gorge (CNC). Haines Jct. (CNC). Haines Rd., kmp 175 (ROM). Klondike Hwy., kmp 476, 562, 572, 626 (ROM). Kluane (UBC). Lake Laberge (UBC). Lapie R. Canyon (ROM). Lower Rancheria R. (ROM). Mayo Rd., kmp 14 (ROM). McQuesten R. (ROM). Money Cr. (ROM). Pelly Crossing (ROM). Pine Cr. (ROM). Quiet Lk. (ROM). Rancheria (UBC). Rose Lk. (UBC). South Canol Rd., kmp 22, 39.5, 154, 172 (ROM). Sulphur Lk. (ROM). Tagish (UBC). Takhanne R. (ROM). Tatchun Cr. (ROM). Teslin (CNC). Watson Lk. Cpgrd. (ROM). Whitehorse (CNC). Willow Cr. (CNC, ROM).

\section{Onocosmoecus sequoiae n.sp.}

Figs. 11-13

Almost all of the several hundred adult specimens examined fall within the bounds of continuous variation described above in the $O$. unicolor complex, except some from a few localities for the most part in the Sierra Nevada Mountains of California. Because these specimens show clear structural differences from $O$. unicolor as defined above, and because intermediate forms have not been 

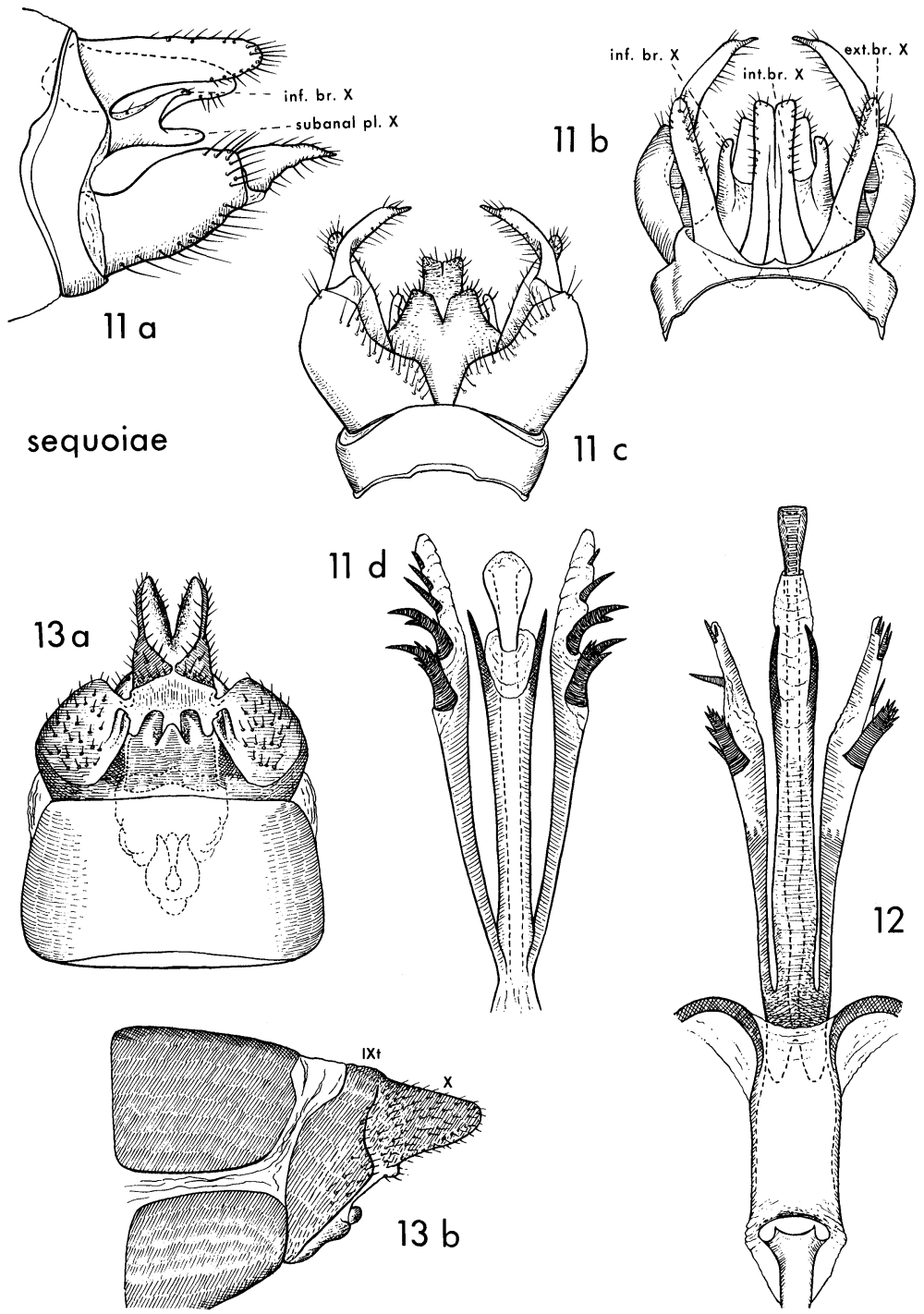

Figs. 11-13. Onocosmoecus sequoiae n.sp. 11, Holotype male, Tulare Co., California, genitalia: a, lateral; b, dorsal; c, ventral; d, phallus. 12, Variant male, Shasta Co., California, phallus. 13, Allotype female, Tulare Co., California, genitalia: a, ventral; b, lateral. (ext. br. X, int. br. X., inf. br. X, external, internal, \& inferior branches of segment X; subanal pl. X, subanal plate of segment X; IXt, tergum of segment IX; X, segment X). 
found, we consider them to represent a distinct and previously unrecognized species.

Adult. Similar to $O$. unicolor in general body characters and venation, but distinguished by characters of the male and female genitalia as outlined in the key to species. Colour more similar to yellowish variants of $O$. unicolor than to the darker brown specimens; dark markings on the fore wings around the corneous spot in cell R4 and around the thyridium variable. Length of the fore wing: ô $18-20 \mathrm{~mm}$; ᄋ $20-21 \mathrm{~mm}$.

Male genitalia (Fig. 11). Segment X with external branches in lateral aspect broad at the base, usually somewhat tapered toward the apex, orientation mainly in a vertical plane; internal branches in dorsal aspect with a double-edged median crest; subanal plate in dorsal aspect extending beyond the periphery of the internal branches; inferior branch of $\mathrm{X}$ prominent as a flattened tongue between the external branch and the subanal plate. Phallus with parameres entirely separate from the aedeagus except at the basal articulation, spines fewer than in $O$. unicolor and bent, proximal spines cusped with small accessory points, apex of each paramere a prominent membranous lobe.

Female genitalia (Fig. 13). Segment IX with tergum consisting of enlarged lateral lobes as in $O$. unicolor, but the lobes concave ventrolaterally; sternum of IX somewhat folded and less sclerotized than in $O$. unicolor. Segment $\mathrm{X}$ in ventral aspect shorter and broader than in $O$. unicolor, and more widely divided dorsally, prominent basal shoulder lacking. Vulval lobe in ventral aspect with median portion wider and more pointed than is usually so in $O$. unicolor.

LARva. Unknown for this species, and consequently Onocosmoecus larvae from the general range of $O$. sequoiae cannot yet be assigned to species.

TYPES. Holotype male (pinned): CALIFORNIA, Tulare Co., Salmon Cr., trib. Kern R., Horsemeadow Campground, Sequoia National Forest, approx. $7000 \mathrm{ft}$., $10 \mathrm{mi}$. NE Kernville, 7 August 1985, black light trap, R. W. Wisseman; Allotype female (pinned), same data as holotype; Paratypes $48 \hat{0} 17$, same data as holotype, specimens pinned and in alcohol. These specimens are deposited in the Department of Entomology, Royal Ontario Museum, Toronto. 


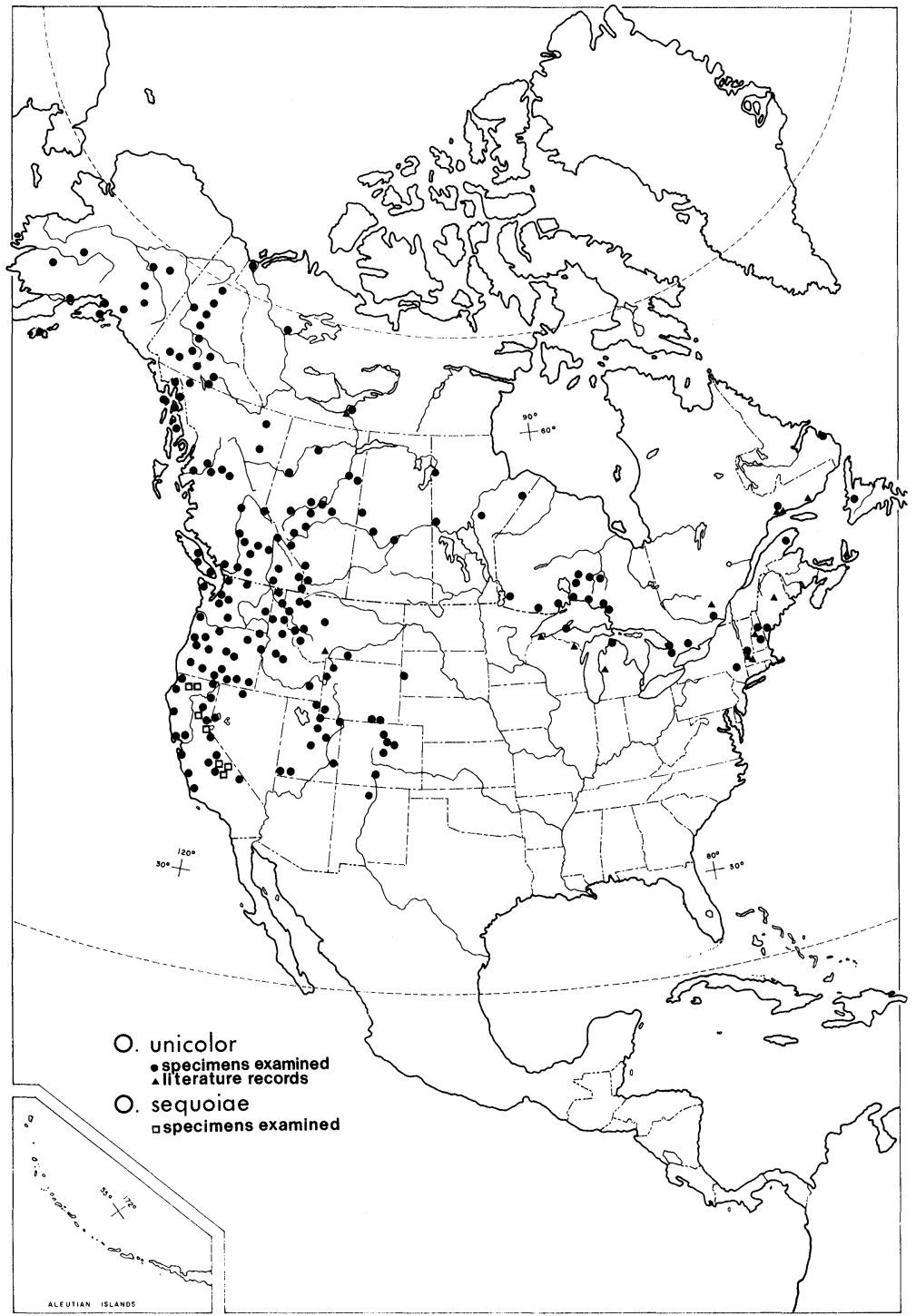

Fig. 14. Nearctic distribution of Onocosmoecus spp. 
Additional Paratypes. CALIFORNIA: El Dorado Co., Tahoe Paradise, 5-13 August 1985, 4ठิ, W. H. Tyson, DGD; 1 mi. SW Meyers, 13 July 1984, 1오, W. H. Tyson, DGD. Madera Co., Red's Meadow, 16 August 1941, 3ô 19, M. V. Hood, LACM; Nelder Cr. Camp, $4600 \mathrm{ft}$., 25 August 1973, 19, W. H. Tyson, USNM; Central Camp, $5500 \mathrm{ft}$., 30 July 1983, 30̂, J. Larson, DGD. Siskiyou Co., Shadow Cr., 7 mi. E Cecilville, 5 September 1968, 1ㅇ, USNM. Tulare Co., Salmon Cr. at Horsemeadow Campground, Sequoia National

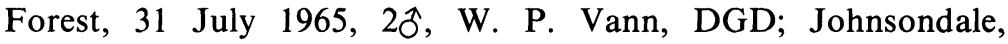
Aug.-Sept. 1985, many ̂ํํํ 우우, uvl, D. J. Burdick, CAS, DJB, USNM, ROM.

From extensive u.v.l. collections made by D. J. Burdick, we have been able to examine long series of adults of $O$. sequoiae. There is no evidence of intergradation between $O$. sequoiae and $O$. unicolor, and both species were represented in two of the series examined: Madera Co., Lewis Cr., 16-22 September 1983; El Dorado Co., 1 mi. SW Meyers, 30 August 1984 (specimens in collection of D. J. Burdick). In two male specimens of $O$. unicolor from Fresno Co. (Friant) the inferior branch of segment $\mathrm{X}$ was an angulate vertical plate, but not the flattened tongue of $O$. sequoiae; and the parameres of these specimens were typical of $O$. unicolor.

RANGE AND HABITAT. Adults of this species have been collected in the vicinity of streams mainly in the Sierra Nevada Mountains of California in El Dorado, Inyo, Madera, Plumas, Shasta, Siskiyou, and Tulare Counties (Fig. 14). In the absence of information on larvae of $O$. sequoiae, any difference in habitat between the two species remains unknown.

VARIATION. Another form, provisionally considered a variant of $O$. sequoiae, has been found in collections from Shasta County (Castle Cr., approx. 3 mi. w. Hwy. I-5, 9 August 1985, 18ત 7q, uvl, ROM; Indian Cr., Castle Crags State Park, 9 August 1985, 10ิ, uvl, ROM; Hat Cr., 25 June 1947, 10, CAS) and Plumas County (Thompson Cr., $0.6 \mathrm{mi}$. above Thompson Meadows, s.w. Quincy, 16-17 July 1985, 10, uvl, ROM). These specimens are larger than most $O$. unicolor and typical $O$. sequoiae (length of fore wing: $\hat{\sigma}$ $21-22 \mathrm{~mm}$; $\$ 23 \mathrm{~mm}$ ), but the principal difference is in the parameres of the males (Fig. 12) where the proximal spine is a long, stout straight process with a cluster of short denticles at the apex. The distal spines on the parameres are reduced in size and nearly 
straight, and the apical membranous lobe is also reduced. The fused internal branches of segment $X$ are more flattened than in the typical form and the median crest less distinct; the external branches of $\mathrm{X}$ tend to be straight-sided and less tapered than in the typical form, but are enlarged apically in one specimen in the Shasta County series. Females of this variant are similar to the typical form.

None of these variant specimens is included in the type material of $O$. sequoiae, and in the continued absence of intermediates, they could be considered as representing a distinct species.

Key to adults of Onocosmoecus s.s. species

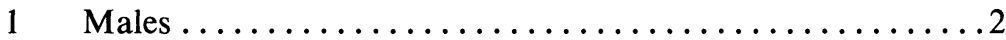

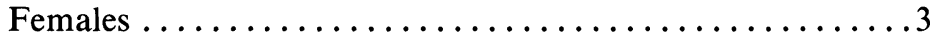

2(1) In lateral aspect, inferior branches of segment $X$ large and well developed into a flattened tongue between the external branch and subanal plate, external branches of $\mathrm{X}$ largely orientated in a vertical plane, frequently broadest at the base and tapering apically (Fig. 11a). Known only from the Sierra Nevada Mountains of eastern California (Fig. 14)......... sequoiae In lateral aspect, inferior branches of segment $X$ usually lacking, occasionally present but very small, external branches of $\mathrm{X}$ oriented more horizontally, frequently narrow at the base and broadened apically (Fig. 2a). Widely distributed in North America including California (Fig. 14) and also far eastern USSR ........................... unicolor

3(1) Segment IX with terga enlarged and bulbous, segment $X$ in ventral aspect a tapered tube, open ventrally but closed dorsally for the most part or with a narrow apical cleft (Figs. 3, 5, $6,7) \ldots \ldots \ldots \ldots \ldots \ldots \ldots \ldots \ldots \ldots$ unicolor Segment IX with terga enlarged but concave ventrolaterally, segment $X$ in ventral aspect tubular but tapered apically little if at all, and cleft both dorsally and ventrally in a broad V-shape (Fig. 13) sequoiae

\section{ACKNOWLEDGMENTS}

This study was completed under financial support (to GBW) from the Natural Sciences and Engineering Research Council of Canada. Field studies were supported by previous grants (to GBW) from the 
National Research Council of Canada (A5707), the U.S. National Science Foundation (G22135) and the Canadian National Sportsmen's Show. For the loan of type specimens and of general collections, we acknowledge the assistance of N. E. Woodley, A. F. Newton and N. D. Stone, Museum of Comparative Zoology, Harvard University; A. Kaltenbach, Naturhistorisches Museum Wien; O. S. Flint, United States National Museum of Natural History; D. G. Denning, Moraga, California; D. J. Burdick, California State University, Fresno; J. D. Unzicker, Illinois Natural History Survey; S. D. Smith, Central Washington State College; A. P. Nimmo, University of Alberta; N. H. Anderson and R. W. Wisseman, Oregon State University; I. M. Levanidova, Institute of Biology and Pedology, Vladivostok; M. W. Oswood, University of Alaska; F. Schmid, Biosystematics Research Institute, Ottawa; L. Zhiltzova, Zoological Institute, USSR Academy of Sciences, Leningrad; W. J. Pulawski, California Academy of Sciences, San Francisco. For assistance with field collections we are indebted to G. W. Courtney, H. E. Frania, E. R. Fuller, R. Jaagumagi, L. H. Kohalmi, B. D. Marshall, C. R. Parker, R. S. Scott, I. M. Smith, R. N. Vineyard, R. W. Wisseman, and T. Yamamoto.

Line drawings were prepared by Anker Odum and Zile Zichmanis of the Royal Ontario Museum. Photographs were made by Brian Boyle, ROM Photography. Susan Pasch, Shakilah Mehrunnisa and E. R. Fuller assisted with the preparation of the manuscript.

\section{SUMMARY}

From analysis of type specimens of the seven putative species of the Onocosmoecus unicolor group and of extensive collections from many localities in North America, six names (Asynarchus tristis Banks, Dicosmoecus coloradensis Ulmer, Anabolia quadrinotatus Banks, Dicosmoecus (O.) occidentis Banks, Dicosmoecus (O.) alascensis Banks all from North America, and Dicosmoecus flavus Martynov from Kamchatka) are proposed as junior subjective synonyms of Onocosmoecus unicolor (Banks). Other variables are discussed and it is concluded that existing evidence shows $O$. unicolor to be a highly variable and widespread species ranging through northern and montane North America to eastern Asia. A new species Onocosmoecus sequoiae is recognized from several localities, mainly in 
the Sierra Nevada Mountains of California. These two species con titute Onocosmoecus s.s.; geographic distribution is summarized and observations on biology are included.

\section{REFERENCES}

Banks, N. 1897. New North American neuropteroid insects. Trans. Am. ent. Soc. 24: $21-31$.

1900. New genera and species of Nearctic neuropteroid insects. Trans. Am. ent. Soc. 26: 239-259.

1908. Some Trichoptera, and allied insects, from Newfoundland. Psyche 15: $61-67$.

1943. Notes and descriptions of Nearctic Trichoptera. Bull. Mus. comp. Zool. 92: 341-369.

Cummins, K. W. 1973. Trophic relations of aquatic insects. Ann. Rev. Entomol. 18: 183-206.

Flint, O. S. 1960. Taxonomy and biology of Nearctic limnephilid larvae (Trichoptera), with special reference to species in eastern United States. Entomologica am. 40: 1-120.

Longridge, J. L. AND W. L. Hilsenhoff. 1972. Trichoptera (Caddisflies) In Aquatic Insects of the Pine Popple River, Wisconsin by W. L. Hilsenhoff et al. Wisconsin Dept. Nat. Resources, Tech. Bull. 54, pp. 1-44.

Martynov, A. V. 1913. Trichoptera of the Kamtshatka expedition. Russk. ent. Obozr. 13: 476-481.

1914. Les Trichoptères de la Sibérie et des régions adjacentes. IV-e partie. Sousfam. Limnophilinae (fam. Limnophilidae). Ezheg. zool. Muz. 19: 173-285.

1925. Trichoptera recueillis au Kamtshatka par l'expédition de Mr. Th. Riabusinskij en 1908-1909. Ezheg. zool. Muz. 26: 10-26.

Ross, H. H. 1938. Lectotypes of North American caddis flies in the Museum of Comparative Zoology. Psyche 45: 1-61.

Roy, D. AND P. P. HARPER. 1979. Liste préliminaire des Trichoptères (insectes) du Québec. Ann. Soc. ent. Québec 24: 148-171.

Schmid, F. 1955. Contribution à l'étude des Limnophilidae (Trichoptera). Mitt. schweiz. ent. Ges. 28.

1980. Genera des Trichoptères du Canada et des États adjacents. Les Insectes et Arachnides du Canada, Partie 7. Can. Agric. Publ. 1692. 296 pp.

Ulmer, G. 1905. Neue und wenig bekannte aussereuropäischeTrichopteren, hauptsáchlich aus dem Wiener Museum. Annln naturh. Mus. Wien 20: 59-98.

1927. Entomologische Ergebnisse der schwedischen Kamtchatka-Expedition 1920-1922. 11. Trichopteren und Ephemeropteren. Ark. Zool. 19: 1-17.

Wiggins, G. B. 1977. Larvae of the North American Caddisfly Genera (Trichoptera). University of Toronto Press, Toronto and Buffalo. $401 \mathrm{pp}$.

Wiggins, G. B. AND J. S. Richardson. 1982. Revision and synopsis of the caddisfly genus Dicosmoecus (Trichoptera: Limnephilidae; Dicosmoecinae). Aquat. Insects 4: 181-217. 
Williams, N. E. AND D. D. Williams. 1979. Distribution and feeding records of the caddisflies (Trichoptera) of the Matamek River region, Quebec. Can. J. Zool. 57: 2402-2412.

Winterbourn, M. J. 1971. The life histories and trophic relationships of the Trichoptera of Marion Lake, British Columbia. Can. J. Zool. 49: 623-635. 

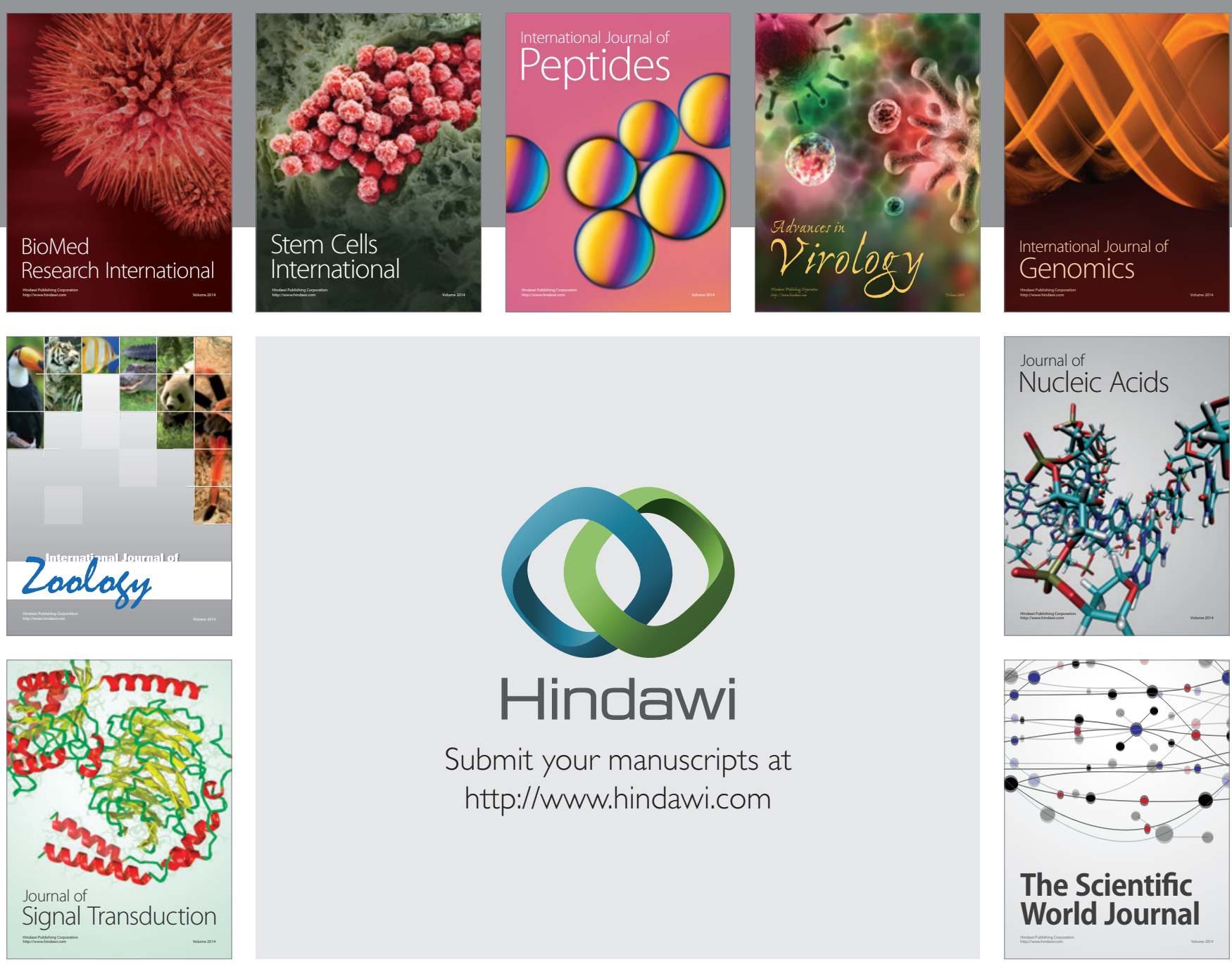

Submit your manuscripts at

http://www.hindawi.com
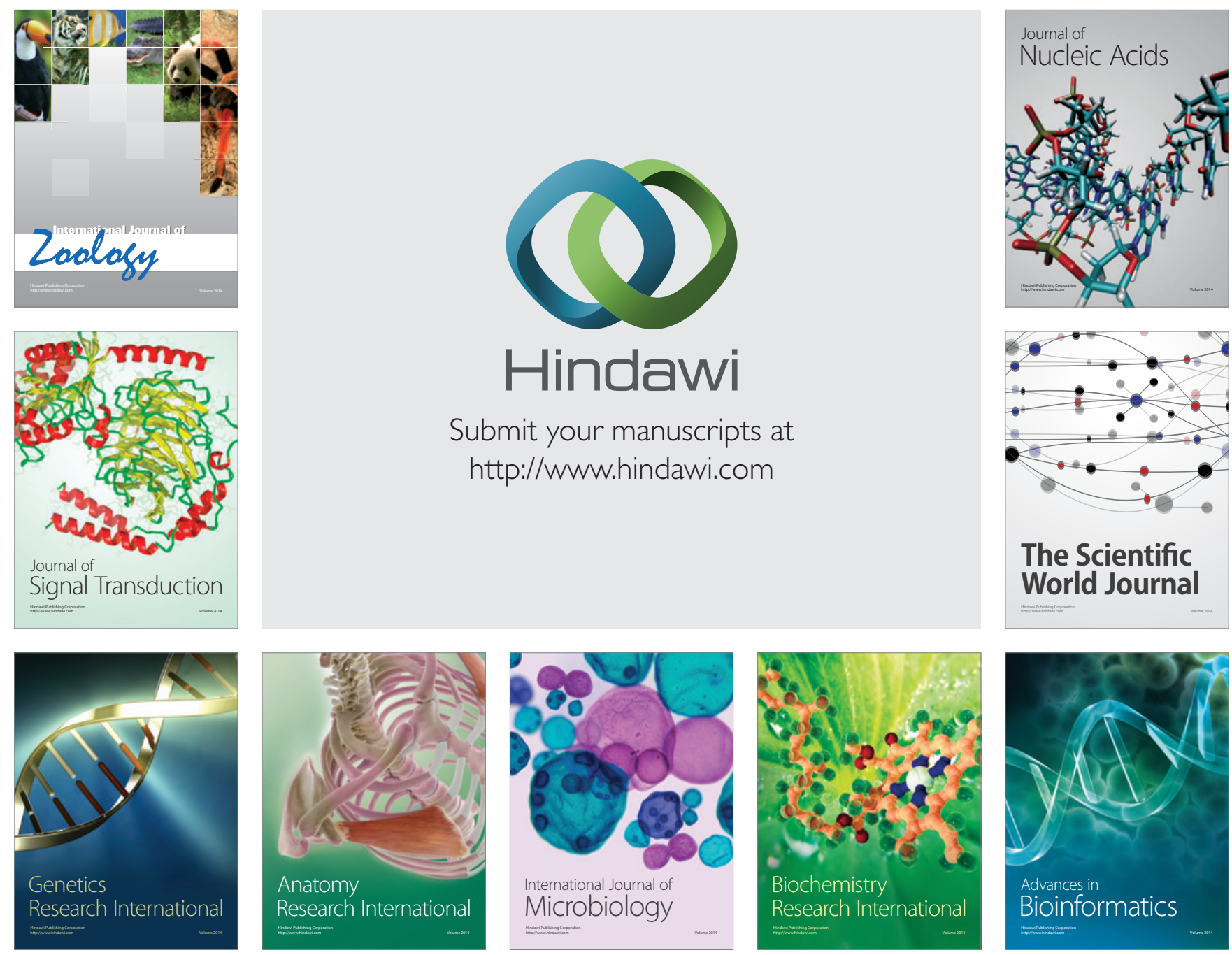

The Scientific World Journal
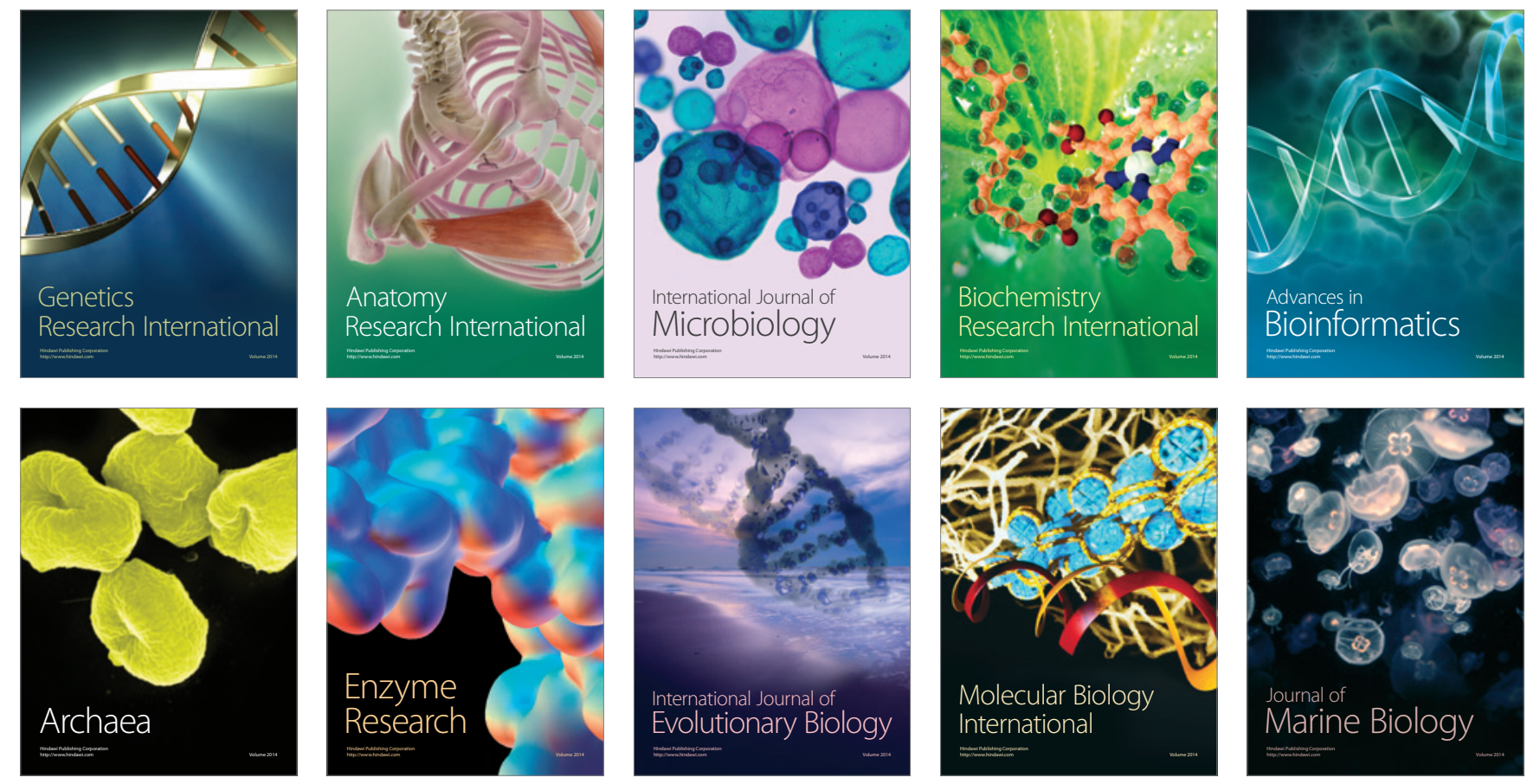